\title{
Kreativitas Musik Gambang Semarang Studi Kasus Komunitas Gambang Semarang Art Company
}

\author{
Ricky Alfiantoro ${ }^{1}$
}

\begin{abstract}
Gambang Semarang is one of the original art Gambang Semarang are adopting Kromong Betawi arts. Gambang Semarang was born in 1930 on the initiative of Lie Soen Hoo who is a member Volkstraad (House of Representatives during the reign of the Netherlands). At present Gambang Semarang has created a form that has a factor in creativity. Creativity is an aspect of human qualities which currently play an important role in supporting the development of the nation Indonesian who are experiencing problems are complex, because creativity will have the ability, the creative adaptation and expertise imaginative, so that people will be able to find a resolution problems in a new way in follow the changes that occur that will continue to move towards progress for not float and sink in competition between nations and countries, especially in this era of globalization.

Gambang Semarang Art Company is a community of young people who are active in preserving the arts Gambang Semarang with attractive feature, which will follow the tastes of the market in contemporary times, a rendition of the popular and also add some western instruments in the ensemble. Their communities Gambang Semarang Art Company is very important to introduce art Gambang Semarang are increasingly recognized by the people of Semarang.

Research Gambang Semarang Art Company uses the description of the analysis method with the approach of ethnomusicology. The results obtained in these studies is a form of imitation of Gambang Semarang are packed in Gambang Semarang Art Company can produce and the continued existence of Gambang Semarang as regional identity.
\end{abstract}

Keywords: Gambang Semarang, Creativity, Community Gambang Semarang Art Company.

\begin{abstract}
Abstrak
Gambang Semarang merupakan salah satu kesenian asli Semarang yang mengadopsi kesenian Gambang Kromong Betawi. Gambang Semarang lahir pada tahun 1930 atas inisiatif dari Lie Hoo Soen yang merupakan anggota Volkstraad (Dewan Perwakilan Rakyat pada zaman pemerintahan Belanda). Pada sekarang ini Gambang Semarang telah dibuat suatu bentuk yang memiliki faktor dalam kreativitas. Kreativitas merupakan suatu aspek dari kualitas manusia yang saat ini sangat berperan penting di dalam menunjang

\footnotetext{
${ }^{1}$ Mahasiswa jurusan Etnomusikologi FSP ISI Yogyakarta.
} 
pembangunan bangsa dan negara Indonesian yang sedang mengalami permasalahan-permasalahan yang kompleks, sebab dengan kreativitas akan memiliki kemampuan, adaptasi kreatif dan kepiawaian yang imajinatif, sehingga manusia akan mampu mencari penyelesaian masalah dengan cara yang baru didalam mengikuti perubahan-perubahan yang terjadi yakni akan terus bergerak kearah kemajuan untuk tidak hanyut dan tenggelam dalam persaingan antar bangsa dan negara terutama di era globalisasi ini.

Gambang Semarang Art Company adalah komunitas anak muda yang aktif dalam melestarikan kesenian Gambang Semarang dengan ciri yang menarik, yakni dengan mengikuti selera pasar pada zaman sekarang, membawakan lagu populer dan juga menambahkan beberapa instrumen barat dalam ansambel tersebut. Adanya komunitas Gambang Semarang Art Company sangat penting untuk memperkenalkan kesenian Gambang Semarang yang semakin tidak dikenal oleh masyarakat kota Semarang.

Penelitian Gambang Semarang Art Company menggunakan metode deskripsi analsis dengan pendekatan etnomusikologi. Hasil yang didapat dalam penelitian tersebut yaitu bentuk imitasi dari Gambang Semarang yang dikemas dalam Gambang Semarang Art Company dapat menghasilkan dan melanjutkan keberadaan Gambang Semarang sebagai identitas daerah.

Kata Kunci: Gambang Semarang, Kreativitas, Komunitas Gambang Semarang Art Company.

\section{Pendahuluan}

Semarang sebagai kota di pesisir pantai utara sebagai daerah yang banyak di singgahi kapal-kapal bangsa asing pada saat itu, sehingga banyak warga asing yang tinggal di kota ini, Salah satunya satunya etnis Cina yang lama singgah dan tinggal di kota ini. Etnis Cina sebagai etnis pendatang dapat membaur dan berinteraksi yang baik, sehingga dari adanya interaksi antar etnis Cina dan etnis Jawa atau pribumi terjadi akulturasi. Salah satu hasilnya kesenian akulturasi dua budaya ini adalah Gambang Semarang. Gambang Semarang sebagai salah satu kesenian Semarang menjadi kesenian akulturasi dua budaya ini. Pada saat itu Gambang Semarang sering dipentaskan di klenteng : Gang Lombok, Gang Baru, Bon Lancung dan lain-lain (Dhanang, 2000: 49).

Gambang Semarang merupakan salah satu kesenian yang besar dan lahir di kota Semarang. Menurut sejarahnya, Gambang Semarang merupakan kesenian yang mengadopsi dari kesenian Gambang Kromong yang berada di Betawi Jakarta. Hal ini dapat dilihat dari alat musik yang digunakan. Awal lahirnya 
kesenian Gambang Semarang merupakan dari inisiatif salah seorang Volkstrad (Dewan Perwakilan Rakyat pada masa penjajahan) Semarang yang juga salah satu pengurus organisasi kesenian Krido Hartojo bernama Lie Hoo Soen yang menginginkan adanya kesenian khas Semarang. Gambang Semarang dibentuk secara melembaga pada sekitar tahun 1930 Dhanang (2000:42), Banyak orang di kota Semarang yang berbakat dalam hal seni pada saat itu, diantaranya Mak Irah dan Mak Royom. Mereka berdua adalah seniwati Gambang Kromong Jakarta yang merantau ke Semarang. Bakat dan kemahiran menari Mak Irah di lihat oleh Lie Hoo Soen dalam suatu pementasan, sehinga Lie Hoo Soen tertarik untuk menampilkan kesenian Gambang Kromong di Semarang, Lie Hoo Soen menjumpai Mak Irah untuk membicarakan maksud kedatangannya untuk mengajak Mak Irah menampilkan kesenian Gambang Kromong, Karena tidak adanya alat musik, atas persetujuan dari walikota Semarang saat itu, Lie Hoo Soen mendatangkan alat-alat musik Gambang Kromong berserta pelatih Gambang Kromong yakni Tjiam Bok Wie untuk melatih para pemain musik yang beliau bentuk, tidak lama mengajar kesenian Gambang Kromong Tjiam Bok Wie pulang ke Jakarta, hal ini sungguh disayangkan, karena kelompok kesenian ini masih butuh seorang pelatih. Atas inisiatif mak Irah, maka mak Irah pulang ke Jakarta untuk mengajak adiknya yang bernama Subadi untuk melatih para pemusik Gambang Kromong. Subadi adalah salah satu seniman Gambang Kromong yang memiliki bakat dalam memainkan semua alat-alat musik Gambang Kromong. Subadi dan mak Irah akhirnya bergabung menjadi seniman Gambang Kromong pimpinan Lie Hoo Soen. Kelompok kesenian di bawah pimpinan Lie Hoo Soen inilah kemudian dikenal dengan sebutan Gambang Semarang.

Gambang Semarang Art Company merupakan salah satu komunitas pelestari Gambang Semarang yang aktiv dalam pengembang kesenian Gambang Semarang. Komunitas ini pertama kali muncul berawal dari acara yang mereka buat dengan tema acara "Titi Wanci Gambang Semarang" dalam wadah UKM Kesenian Jawa yang dipelopori oleh para alumni UKM Kesenian Jawa, pada waktu itu tempat pementasanya berada di Banicastle yang dulu merupakan rumah megah dari Oie Tiong Ham salah satu saudagar gula terkaya di Asia Tenggara. 
Pemetasan dilaksanakan di Baniecastle merujuk pada ide dan pemikiran mereka yang mengacu pada sejarah, bahwa dulu di masa keemasan Gambang Semarang, tempat yang digunakan untuk pementasan musik Gambang Semarang pimpinan Lie Hoo Soen. Mulai saat itulah semangat mereka dalam melesatrikan dan memainkan musik Gambang Semarang muncul. Salah satu gagasan dari Tri Subekso adalah, jika kesenian Gambang Semarang ingin eksis, mereka tidak hanya memainkannya dalam wadah UKM kesenian Jawa, tetapi juga harus dikembangkan dalam satu bentuk komunitas. Gagasan ini didukung oleh temanteman angota lainya, yakni Fitriyanto GS, Putut Bayu, Frida, Kusri Handoyo dan Sandra (ketua UKM Kesenian Jawa pada saat itu). Pada tanggal 20 november 2012 mereka berkumpul malam hari di depan rumah Tri Subekso, pada hari berikutnya dan tempat yang sama pada tanggal 21 November 2012, tepat tiga tahun semenjak mereka pentas pertama kali di Beniecastle mereka berenam mendeklarasikan berdirinya Komunitas Gambang Semarang tepat pada jam 00.01 tanggal 21 November 2012.

Menurut penuturan ketua Gambang Semarang Art Company Tri Subekso, Semenjak Gambang Semarang Art Company dideklarasikan pada tanggal 21 November 2012, mereka mulai bergerak dengan tujuan pertama yakni memperkenalkan dan mensosialisasikan bahwa Komunitas Gambang Semarang Art Company adalah komunitas yang meneruskan dan mengenalkan kesenian Gambang Semarang kembali. Hal ini tercetus semenjak meninggalnya bapak Jayadi yang merupakan salah satu seniman terakhir yang aktif di kesenian Gambang Semarang. Berkat semangat dan kerja keras Komunitas Gambang Semarang Art Company, maka pada tanggal 12 Desember 2012 bertempat di Sanggar Sobokarti mereka mengadakan pementasan pertama kali dengan nama Komunitas Gambang Semarang Art Company.

Setelah pementasan di Sanggar Sobokarti pada saat itu, Gambang Semarang Art Company menjadi dikenal sebagai komunitas yang melestarikan dan mengembangkan kesenian Gambang Semarang, mereka juga sering mementaskan kesenian Gambang Semarang ke kampung-kampung sekitar basecamp mereka dengan tujuan memperkenalkan kembali kesenian Gambang 
Semarang yang kurang dikenal oleh masyarakat. Anggota Gambang Semarang Art Company terdiri dari mahasiswa dan alumni UKM Kesenian Jawa di Universitas Diponegoro Semarang, tetapi juga mengajak seniman-seniman sekitar, misalnya seperti seniman Tionghoa. Menurut penuturan Tri Subekso anggota GSAC tidak semua berlatar belakang dari musik, mereka belajar dari nol, sehingga musikalitasnya masih standar.

Gambang Semarang Art Company mempunyai tempat berkumpul di PKM (Pusat Kegiatan Mahasiswa) terletak di Peleburan yang berada di kampus dua Universitas Diponegoro. Setelah mereka lahir sebagai komunitas, alat musik Gambang Semarang tidak bisa leluasa mereka mainkan, Karena pemilik alat musik (Fakultas Ilmu Budaya) membawanya ke kampus satu yang terletak di Tembalang kira-kira jaraknya 10 km dari kampus PKM Peleburan. Ketika mereka ada jadwal pementasan, mereka harus meminjam alat musik ke Fakultas Ilmu Budaya melalui perizinan yang tidak mudah, masalah surat menyurat yang sangat rumit dari pihak Fakultas Ilmu Budaya. Hal seperti ini dirasakan kurang leluasa oleh para anggota GSAC, karena waktu mereka berlatih terbatasi, sehingga setiap ada pementasan, mereka harus berlatih dengan ringkas, hal inilah yang dirasakan kurangnya bagi para anggota dalam mengeksplor musik. Kesulitan dalam peminjaman alat ini terjadi karena alat musik juga digunakan oleh grup Kesenian Gambang Semarang atau lebih dikenal dengan singkatan KGS di bawah naungan Fakultas Ilmu Budaya. Sedangkan grup KGS secara materi di bawah bimbingan anggota GSAC yang dulu aktif di UKM Kesenian Jawa. Hal ini yang membuat anggota serta pengurus berinisiatif mengumpulkan dan mencari donatur untuk membeli alat musik sendiri. Tidak lama kemudian komunitas GSAC mampu membeli alat musik dan sebagian dari donatur, adapun alat musiknya masih terbatas yang terdiri dari saron, peking dan demung.

\section{Kreativitas Musik Gambang Semarang}

Kesenian sebagai bagian dari kebudayaan adalah merupakan olah kreativitas manusia yang terus maju ke depan (Eli Irawati, 2013: 126). Proses 
kreativitas hadir dari dalam pikiran manusia seiring dengan semakin berkembangnya pemikiran, media internet serta semakin terbukanya wawasan manusia. Kreativitas merupakan suatu aspek dari kualitas manusia yang saat ini sangat berperan penting di dalam menunjang pembangunan bangsa dan negara Indonesian yang sedang mengalami permasalahan-permasalahan yang kompleks, sebab dengan kreativitas akan memiliki kemampuan, adaptasi kreatif dan kepiawaian yang imajinatif, sehingga manusia akan mampu mencari penyelesaian masalah dengan cara yang baru didalam mengikuti perubahan-perubahan yang terjadi yakni akan terus bergerak kearah kemajuan untuk tidak hanyut dan tenggelam dalam persaingan antar bangsa dan negara terutama di era globalisasi ini. Kreativitas merupakan kegiatan yang sifatnya : baru (novelty) yang berati inovasi, belum pernah ada dan aneh; berguna (useful), yang berati lebih praktis, mempermudah, mengatasi kesulitan dan menghasilkan yang lebih baik; dimengerti (understandable), yang berati hasil yang sama dapat dimengerti atau dipahami dan dapat dibuat pada waktu yang berbeda (Iman Setyabudi, 2011: 2) Peryataan tersebut menujukan bahwa kreativitas juga bisa dimengerti atau dipahami dan dapat dibuat pada waktu yang berbeda, hal ini mendasari munculnya inovasi pada komunitas GSAC dalam memperkenalkan kembali Gambang Semarang ke masyarakat kota Semarang pada khususnya dan masyarakat luar kota Semarang pada umumnya dalam satu komunitas Gambang Semarang Art Company dengan rata-rata anggotanya merupakan anak muda. Walaupun belum adanya alat musik Gambang Semarang yang GSAC miliki.

Ide awal terbentuknya komunitas Gambang Semarang Art Company berawal dari peran salah satu grup musik Gambang Semarang Fakultas Sastra Universitas Diponegoro, GSAC mengembangkan lagi Gambang Semarang Fakultas Sastra, dengan pedoman buku penelitian dari Dhanang Respati Puguh yang masih digunakan sampai saat ini. Kreativitas bisa hadir karena adanya pengaruh-pengaruh dari sekitar lingkungan tempat hidup manusia. Seperti halnya komunitas Gambang Semarang Art Company yang mencoba berinovasi dengan kreativitas anggota-anggota di dalamnya yang kemudian dengan caranya yang unik mencoba memperkenalkan dan sekaligus membawakan kesenian Gambang 
Semarang yang kurang dikenal masyarakat kota Semarang. Sajian musik baru dan unik berbeda dengan Gambang Semarang yang sebelumnya, seperti banyak memasukan unsur-unsur musik modern dan tetap pada jalur tradisional. Tidak hanya musiknya yang mendapat sentuhan baru dan unik, tetapi juga pertunjukan lawak.

Seni metamorfose (art by metamorphosis) yang disebut juga seni akulturasi (art of acculturation), karena seni pertunjukan tersebut dalam penggarapannya telah mengalami proses akulturasi (R.M Soedarsono, 2010: 272). Munculnya proses kreativ karena adanya proses penggarapan musik yang diaransemen dan memasukkan gaya selain musik aslinya, hal ini juga tetap menganut pada kaidah tradisional. Kreativitas disini masih sebatas dalam adanya proses mengaransemen saja, masih belum adanya karya yang menjadikan identitas dari komunitas GSAC. Komunitas GSAC memberikan sesuatu yang menarik untuk memberikan warna baru dalam kesenian Gambang Semarang tetapi tidak meninggalkan identitas aslinya. Perkembangan dalam pola garapan misalnya kita dapat melihat mereka mengkolaborasikan segala macam genre musik popular ke dalam musik (Eli Irawati, 2013: 82).Gambang Semarang dengan idiom musik keroncong dan pop. Hal ini dilihat dari sajian lagu yang diaransemen dalam setiap penampilanya serta juga membawakan lagu pop, serta lagu yang sedang populer dimasyarakat saat ini. Penambahan lagu popular pada zaman sekarang diperlukan untuk menambah terhiburnya para penonton. Irama keroncong sangat lekat pada setiap penampilan GSAC, selain menggunakan alat musik Gambang Semarang Komplit mereka juga menggunakan alat musik keroncong dengan tujuan membantu ketika ada job pada acara pernikahan, tidak hanya membawakan lagu-lagu asli Gambang Semarang, tetapi juga lagu keroncong, pop lawas dan lagu-lagu Barat.

Penampilan lagu baru dan populer tidak hanya salah satu kreativitasnya, tetapi di komunitas GSAC juga menambahkan beberapa instrumen di luar alat musik Gambang Semarang, misalnya Yanqin alat musik petik dari Cina, contra bass, cak cuk yang merupakan alat musik dalam musik keroncong. Masuknya alat musik keroncong juga sebagai antisipasi jika peminjaman alat ke universitas 
Diponegoro tidak bisa, sehingga pementasan tetap jalan, walaupun tidak sepenuhnya menggunakan alat musik Gambang Semarang. Zaman modern menuntut orang untuk selalu berinovasi dengan kemampuan yang ada dan bagaimana kita dapat menampilkan suatu pertunjukan yang dapat memikat dan menjadi menarik terhadap pendengarnya.

Komunitas Gambang Semarang Art Company memainkan banyak instrument. Tidak semua instrument yang dimainkan pada komunitas ini adalah milik komunitas. Ada beberapa alat yang dimiliki yakni, saron, demung, dan peking, sementara yang meminjam dari Fakultas Ilmu Budaya yakni, gambang, gambang bass, gong kempul, bonang dan selain itu merupakan milik pribadi dari pemainnya. Tidak semua alat musik digunakan pada setiap repertoar lagu, misalkan dalam pementasan yang menggunakan alat musik Gambang Semarang lengkap, maka cak dan cuk tidak dimainkan begitu juga sebaliknya tapi tidak menutup kemungkinan untuk dimainkan berkolaborasi. Pada lagu Viva La Vida, alat musik erhu, gong dan suling tidak dimainkan. Adapun alat musik dari komunitas Gambang Semarang Art Company yakni :gambang, gambang bass, bonang, gong, kempul, saron, demung, peking, kecrek, simbal, contrabass, cak, cuk, erhu, yangqin, suling, tambur dan kendang.

Transkripsi adalah menyalin sesuatu ke dalam satu bentuk yang dapat dibaca. Dalam menjelaskan atau mendeskripsikan bentuk musik diperlukan dua cara pendekatan. Kedua cara pendekatan tersebut pada dasarnya sangat berguna dan dianggap penting yaitu menganalisis dan mendeskripsikan apa yang didengar kemudian mendeskripsikan apa yang lihat (Nettl, 1964: 98). Charles Seeger juga menyebutkan dua pendekatan untuk menganalisis yaitu pendekatan preskriptif dan deskriptif. Pendekatan preskriptif merupakan pendekatan yang menuliskan bagian-bagian yang menonjol dalam musik saja. Sedangkan deskriptif adalah mentranskripsikan dengan menuliskan secara detail atau kata-kata. Transkripsi sangat diperlukan dalam menganalisis suatu lagu karena mempermudah mengetahui sebuah bangunan lagu melalui media visual yaitu berupa not balok, not angka, not huruf, maupun simbol-simbol lain yang dapat mempermudah untuk melihat suatu bentuk lagu. 
Bentuk musik adalah suatu ide atau gagasan yang meliputi semua unsur musik dalam sebuah komposisi (melodi, irama, harmoni, dan dinamika) (Prier, 2004: 2). Ilmu bentuk Analisis digunakan untuk mengetahui secara detail bagianbagian sampai yang terkecil dalam "bangunan" musik itu sendiri supaya lebih jelas, baik itu yang tampak ataupun tidak. Salah satunya adalah salah satu bentuk lagu Viva la Vida dari band Coldplay yang dibawakan oleh komunitas GSAC dengan komposisi idiom musik Gambang Semarang. Lagu Viva la Vida merupakan salah satu lagu yang dibawakan oleh komunitas Gambang Semarang Art Company sebagai lagu penutup di setiap penampilanya. Pemilihan lagu berdasarkan dari pola ritme lagu yang membangkitkan semangat. Pemilihan Viva la Vida sebagai lagu pokok, yakni bahwa komunitas ini juga bisa dalam membawakan lagu popular sesuai dengan konsumsi masyarakat saat ini, mengimbangi dengan lagu populer yang menjadi daya tarik masyarakat untuk dapat menikmati musik tradisional yang juga bisa membawakan lagu populer.

Intro atau introduksi (introduction) adalah kalimat musik biasanya terdapat pada awal lagu atau sebuah melodi "pendahuluan" untuk memperkenalkan sebuah lagu. Namun tidak semua lagu terdapat suatu introduksi. Introduksi berfungsi sebagai semacam judul (Prier, 2004: 91).

Pada penggarapan lagu Viva la Vida oleh komunitas Gambang Semarang Art Company diawali dengan intro yang dimainkan oleh perkusi yang terdiri dari tambur dan kendang dengan aksen pada tiap 2 birama dihitungan pertama. Tempo yang dimainkan yakni allegro. Tempo allegro merupakan jenis tempo musik yang cepat, riang dan lincah (Soeharto, 1981: 3). Tempo allegro dimainkan pada kisaran M.M 120-132 dengan nada dasar D mayor. Motif pukulan yang sama dimainkan oleh kendang dan tambur, serta permainan kecrek mulai main pada birama 4 memainkan pukulan sesuai tempo. Ritme pada lagu ini dari awal sampai akhir sama dengan dimainkan secara unison dan hanya ada dibeberapa yang terdapat selingan interlude dan riddle canon. Riddle canon merupakan kanon yang mempertunjukan awal kalimat lagu, selanjutnya diserahkan pengembangannya kepada pemain secara improvisasi. 

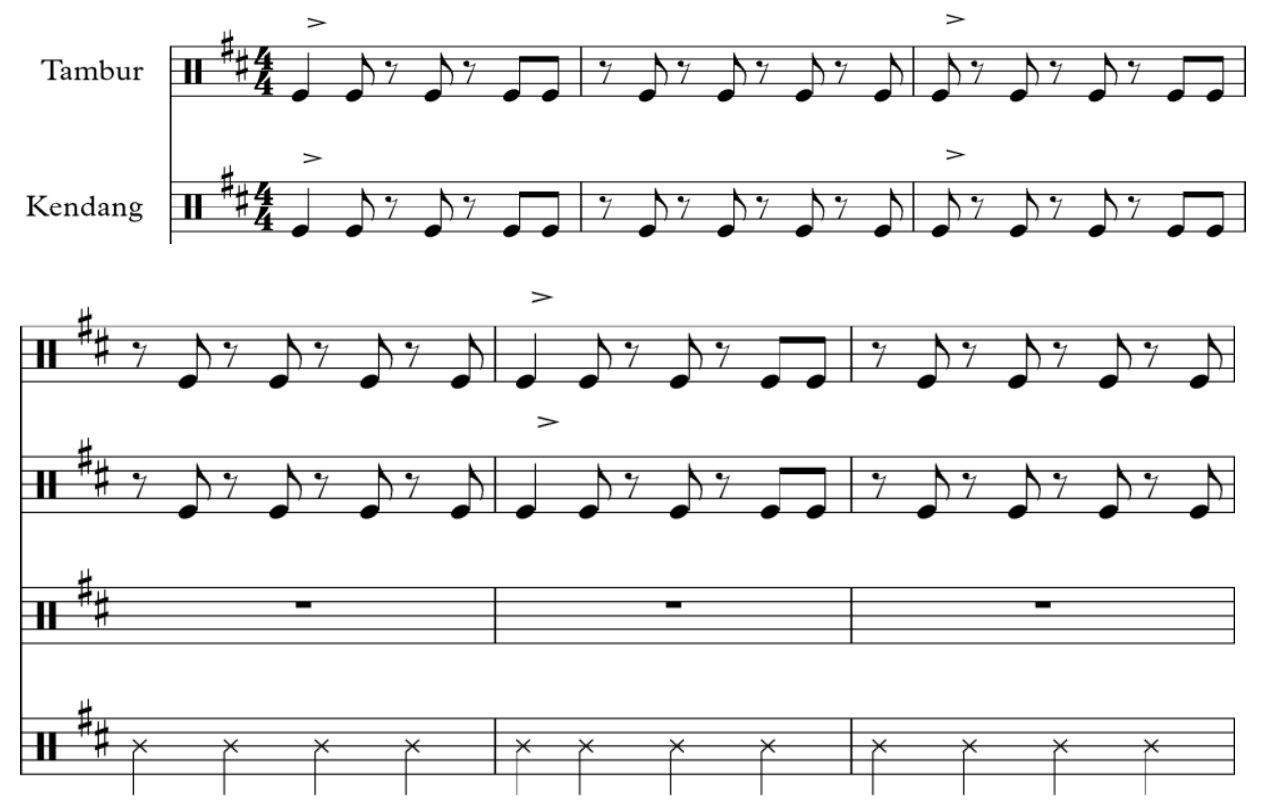

Pada birama 9 semua alat musik memainkan ritme yang sama dengan perkusi dengan progression akord IV( G) V (A) iii (F\#m) vi (Bm). Akord ini dimainkan dari awal sampai akhir lagu tanpa perubahan.

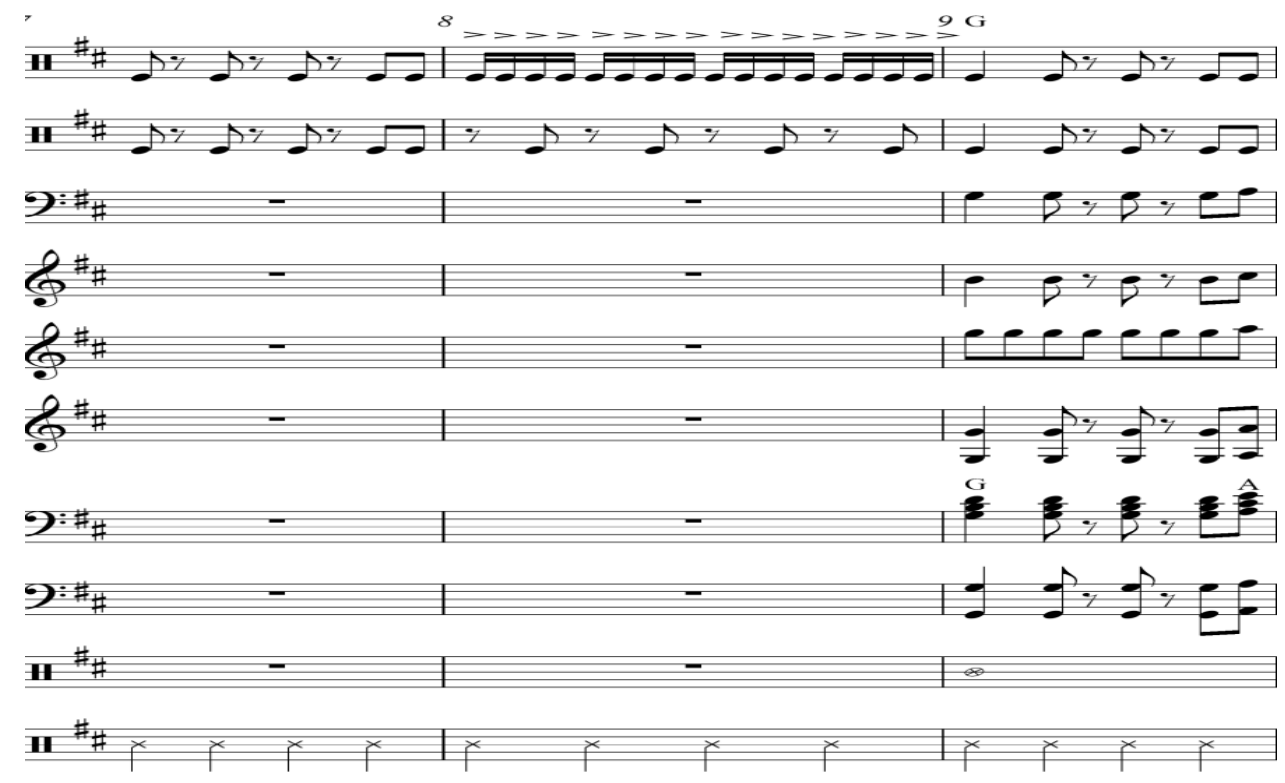




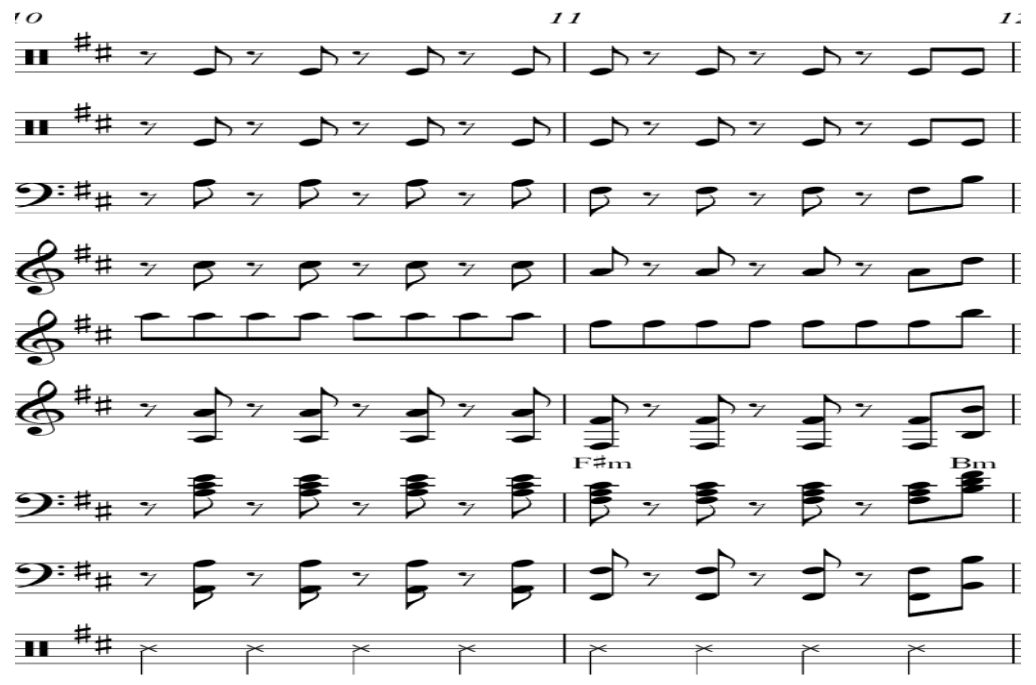

Pukulan kecrek mulai berubah, setelah masuknya vokal pada birama 25 serta pukulan perkusi dan alat musik lain melembut dengan masuknya vokal.

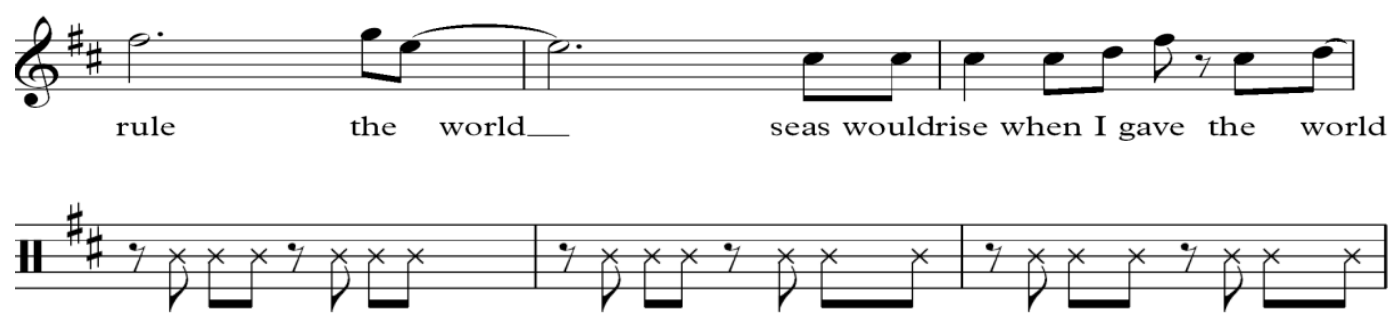

Lagu Viva la vida merupakan lagu dua bagian, karena terdapat kontra yang dapat berwujud: kontras dinamika, kontras irama, kontras tonalitas, kontras harmoni dan kontras arah lagu, ulangan pun dapat dimaksudkan sebagai kontras: pertama kali dibawakan keras, waktu ulanganya dibawakan sebagai 'gema' dengan lembut (Prier, 2004: 10).

Pada bagian A lagu Viva la Vida bermain dimulai pada birama 24-56 dengan selingan interlude pada birama 33-39. Bagian A terdiri dari kalimat tanya (antecedens) dan kalimat jawab (consequens) yang diulang dua kali sama persis dengan satu motif disetiap kalimatnya. Kalimat tanya terlihat menggantung sedangkan kalimat jawab mengakhirinya dengan kembali ke tonika.

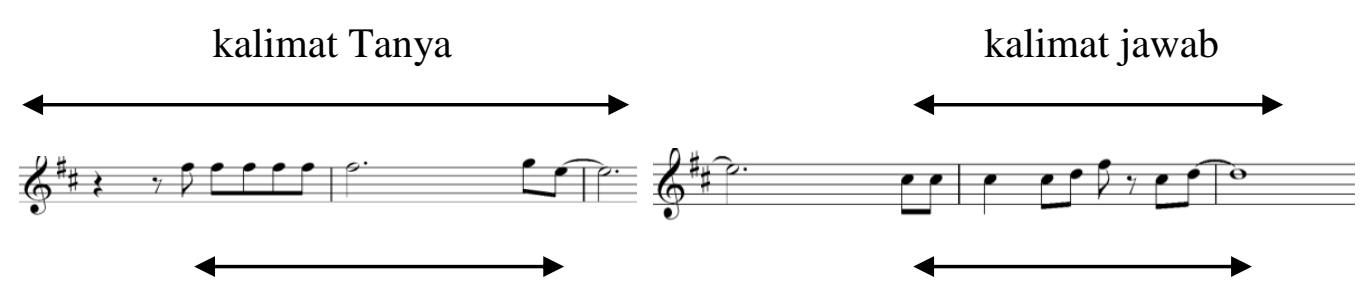


Pada bagian B terdiri dari kalimat tanya (antecedens) dan Kalimat jawab (consequens) yang diulang dua kali sama persis, melodi terlihat berbeda dengan dengan bagian A, karena adanya pengembangan melodi dan karakter suara vokal yang keras dengan penuh semangat.

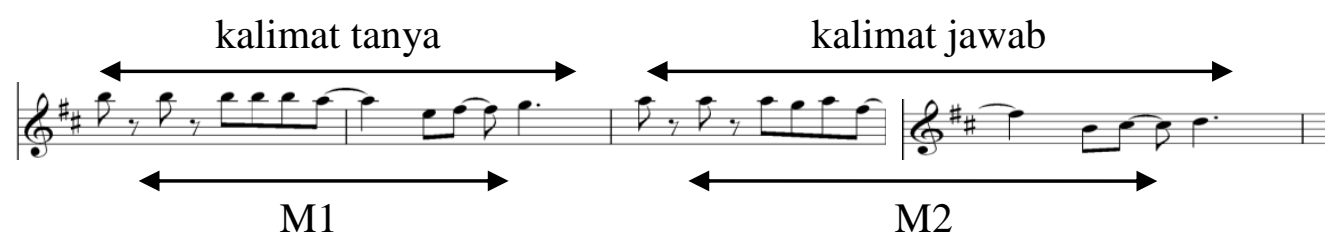

Bagian B juga ditemukan motif pengembangan yang terdapat pada pengulangan kalimat ke tiga.

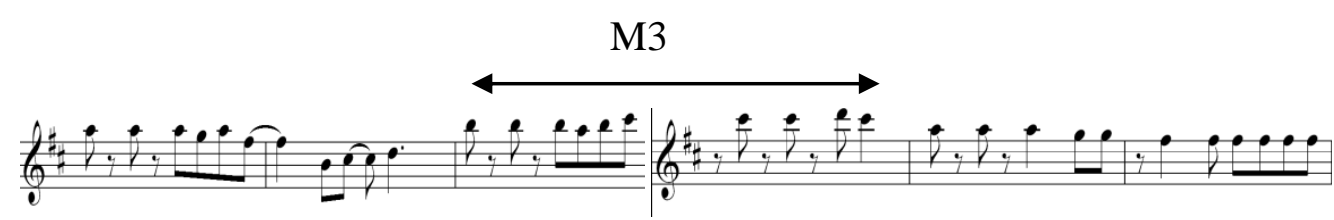

Pada birama 108-116 terdapat interlude dengan syair tambahan, selanjutnya kembali ke reff B' dan berakhir coda. Coda adalah bagian akhir sebuah lagu yang merupakan tambahan guna menyatakan berakhirnya lagu tersebut, pada lagu Viva la Vida garapan komunitas Gambang Semarang Art Company menggunkan coda yang terdapat pada birama 133-136

\section{Kesimpulan}

Melihat dari pembahasan di atas dapat disimpulkan, bahwa komunitas Gambang Semarang Art Company (GSAC) merupakan komunitas yang melestarikan dan mengembangkan kesenian tradisional Gambang Semarang yang menitik beratkan pada nilai aktual dan kreativitas.

Nilai aktual terlihat dari salah satu komunitas yang mengkombinasikan instrument di luar alat musik Gambang Semarang. Tidak hanya pada penambahan alat saja, tetapi materi lagu yang dimainkan menggunakan lagu-lagu popular yang sedang digemari masyarakat, serta lawakan yang dibawakan sesuai dengan 
dengan acara yang sedang diikuti. GSAC membuktikan bahwa kesenian Gambang Semarang juga dapat dimainkan oleh anak-anak muda dan juga bisa menjadi pelopor dalam melestarikan kesenian Gambang Semarang yang sudah sulit dijumpai. Pengembangan dan pelestarian di dalam kesenian ini juga mengandung nila-nilai sosial yang bermaksud saling menjaga dan menghargai antara akulturasi dua budaya Cina dan Jawa yang hidup berdampingan hingga sekarang.

Kesenian Gambang Semarang sebagai salah satu seni yang asli dari kota Semarang, alangkah baiknya kita lestarikan, kita jaga, kita kembangkan sesuai dengan konsumsi masyarakat pada saat ini, tetapi tetap pada latar tradisionalnya. GSAC sebagai salah satu komunitas yang aktif tetap menjaga dan mengembangkan kesenian Gambang merupakan sebuah terobosan yang baik.

Komunitas Gambang Semarang Art Company tetap semangat berproses dan selalu semangat untuk memperkenalkan kesenian Gambang Semarang kepada masyarakat kota Semarang maupun luar kota Semarang. Selalu berani mencoba hal-hal baru dan tetap berkreasi di dalam proses berkesenian, munculkan keanekaragaman aransemen yang menarik meskipun itu lagu lama. Saling bertukar ilmu dan pengalaman dengan komunitas Gambang Semarang yang ada, sehingga dapat menjalin silaturahmi dalam berkesenian dalam kota Semarang. Untuk selanjutnya, perlu dilakukan stem nada yang baik untuk nada instrument peking, saron dan demung dengan menggunakan tuner. Sehingga nada yang dihasilkan dapat sama dengan alat musik pendukung lainnya.

Bagi dinas terkait bisa mengapresiasi salah satu tindakan komunitas ini dalam melestarikan dan mengembangkan kesenian Gambang Semarang, alangkah baiknya juga ikut dalam bertindak dalam mendukung dalam keberlangsungan kesenian yang asli Semarang dan memberikan sarana dalam pengembangan serta pelestarian kesenian Gambang Semarang, dapat juga memberikan sarana dalam bentuk alat musik Gambang Semarang, yang kemudian dari sinilah dapat member pengajaran kepada masyarakat kota semarang pada khususnya. Hal ini merupakan aset berharga bagi pemerintah kota Semarang, karena sudah terdapat komunitas sudah mengembangkan dan melestarikan kesenian Gambang Semarang 
Karya tulis ini sangat jauh dari kesempurnaan, harapan kedepannya penulis selalu dapat memperbaiki dan belajar serta mengembangkan untuk bisa menyumbangkan pemikiran dan perbuatan dalam perkembangan kesenian Gambang Semarang yang masih kurang diketahui oleh masyarakat luas.

\section{Daftar Pustaka}

Azwar, Saifudin. 1997. Metode Penelitian. Yogyakarta: Pustaka Pelajar.

Banoe, Pono.2003. Kamus Musik. Yogyakarta: Kanisius.

Cahyono, Agus. 2006. "Seni Pertunjukan Arak-arakan dalam Upacara Tradisional Dugderan di Kota Semarang", dalam Harmonia Jurnal Pengetahuan dan Pemikiran Seni, Vol. VII No. 3: 2

Hapsari, Lisa. 2013. "Analisis Gaya Tari Semarangan Sebagai Identitas Masyarakat Kota Semarang". Tesis untuk mencapai derajat Sarjana S-2 Program Pengkajian Seni Minat Utama Seni Tari, Institut Seni Indonesia Yogyakarta.

Hendarto, Sri.2011. Organologi dan Akustika I\&II. Bandung: CV. Lubuk Agung.

Irawan, Cepi.2006. "Sastra Lagu Dalam Tembang Sunda". Yogyakarta: Lembaga Penelitian Institut Seni Indonesia Yogyakarta.

Irawati, Eli. 2013. Eksistensi Tingkilan Kutai Suatu Tinjauan Etnomusikologis. Yogyakarta: Kaukaba Dipantara.

Kayam, Umar.1981. Seni, Tradisi, Masyarakat. Jakarta: Sinar Harapan.

Mack, Dieter. 1996. Ilmu Melodi Ditinjau Dari Segi Budaya Barat. Yogyakarta: Pusat Musik Liturgi, cetakan kedua.

Merriam, Alan P. 1964. The Anthropology of Music, Terj. Bramantyo. Chicago: North-westrn University Press.

Muhammad, Djawahir. 1995. Semarang Sepanjang Jalan Kenangan. Semarang: Kerja Sama DKJT, Pemda Semarang dan Aktor Studio.

Nettl, Bruno. 2012. Teori dan Metode dalam Etnomusikologi terj. Nathalian H.P.D. Putra. Jayapura: Jayapura Center of Music.

Prier SJ, Karl-Edmund. 2004. Ilmu Bentuk Musik. Yogyakarta: Pusat Musik Liturgi. 
Respati Puguh, Dhanang. 2000. "Penataan Kesenian Gambang Semarang Sebagai Identitas Budaya Semarang". Laporan penelitian. Semarang: Proyek Pengkajian dan Penelitian Ilmu Pengetahuan Terapan Direktorat Jendaral Pendidikan Tinggi Departemen Pendidikan dan Kebudayaan.

Setyabudi, Iman . 2011. "Hubungan Antara Adversity dan Intelgensi Dalam Kreativitas”, dalam Jurnal Psikologi, Vol. IX No. 1: 2

Soedarsono. 2002. Seni Pertunjukan Indonesia Di Era Globalisasi. Yogyakarta: Gadjah Mada University Press.

Soeharto. M . 1992. Kamus Musik. Jakarta: PT Gramedia Widiasarana Indonesia.

Soempeno, Soerjo. 1979. Sejarah Kota Semarang. Semarang: Pemerintah Daerah Kotamadia Dati II Semarang.

Strauss, Anselm dan Corbin, Juliet, 2003. Dasar-Dasar Penelitian Kualitatif, Terj. Muhammad Shodiq dan Imam Muttaqien. Yogyakarta: Pustaka Pelajar.

Sudjarwo dan Basrowi. 2009. Manajemen Penelitian Sosial Bandung: CV Mandar Maju.

Sukotjo. 2001. "Ansambel Musik Gambang Kromong Betawi dan Ansambel Musik Gambang Semarang Sebuah Studi Komparatif". Laporan Penelitian. Yogyakarta: Balai Penelitian Institut Seni Indonesia Yogyakarta.

Suliyati, Tietik. Dinamika Kawasan Etnis di Semarang. http://eprints.undip.ac.id. akses 1 Oktober 2016.

Syafei. Epe.1983/1984. Sastra Lagu Sunda. Bandung: Proyek Pengembangan Institut Kesenian Indonesia Sub Proyek Akademi Seni Tari Indonesia. 